\title{
MORPHOLOGICAL CHARACTERISTICS AND FORAGE PRODUCTIVITY OF IRRIGATED CACTUS PEAR UNDER DIFFERENT CUTTING INTENSITIES ${ }^{1}$
}

\author{
GUILHERME FERREIRA DA COSTA LIMA ${ }^{2 *}$, MARGARETH MARIA TELES REGO ${ }^{3}$, FERNANDA DANIELE \\ GONÇALVES DANTAS ${ }^{4}$, RAIMUNDO NONATO BRAGA LÔBO ${ }^{5}$, JOSÉ GERALDO MEDEIROS DA SILVA², \\ EMERSON MOREIRA DE AGUIAR ${ }^{6}$
}

\begin{abstract}
This study evaluated the effect of different cutting intensities and years of harvesting on the morphological characteristics and production of fresh (FMP) and dry matter (DMP) of cactus pear cv. Gigante (Opuntia ficus-indica Mill) under conditions of irrigation, high planting density and fertilization, with 12 months of regrowth. The experimental was completely randomized in a factorial design $(3 \times 2)$ with 12 replicates. The treatments were three cutting intensities (preserving the mother cladode (PMC), primary cladodes (PPC), or secondary cladodes (PSC)), and two years of harvesting. The soil was classified as Cambisol Haplicum and the irrigation water was classified as C4S1 (EC $5.25 \mathrm{dS} . \mathrm{m}^{-1}$ ) density of 50,000 plants $\mathrm{ha}^{-1}$. The research evaluated plant height, number of cladodes per plant (NCP), length, width, perimeter and thickness of the cladodes, cladode area (CA), cladode area index (CAI), FMP and DMP. There was no significant interaction between treatments $(P>0.05)$ for the variables plant height, NCP, CAI and FMP. The variables related to cladode morphology showed a significant interaction $(P<0.05)$. The treatment PSC resulted in a greater DMP $(P<0.05)$ with a mean of $27.17 \mathrm{Mg} \mathrm{ha}^{-1} \mathrm{yr}^{-1}$, compared to PPC $\left(18.58 \mathrm{Mg} \mathrm{ha}^{-1} \mathrm{yr}^{-1}\right)$ or PMC $\left(11.78 \mathrm{Mg} \mathrm{ha}^{-1} \mathrm{yr}^{-1}\right)$. The treatment PSC promoted greater NCP and forage productivity at harvest and can be considered as a management practice for the sustainability of cactus pear cv. Gigante under irrigation. The more important morphological characteristics were also influenced by the lower cutting intensities.
\end{abstract}

Keywords: Cactaceae. Forage reserves. Irrigation. Opuntia fícus-indica. Semiarid.

\section{CARACTERÍSTICAS MORFOLÓGICAS E PRODUTIVIDADE DA PALMA FORRAGEIRA IRRIGADA SUBMETIDA A DIFERENTES INTENSIDADES DE CORTE}

\begin{abstract}
RESUMO - A pesquisa objetivou avaliar o efeito de diferentes intensidades de corte e anos de colheita, sobre características morfológicas e produções de matéria verde (PMV) e seca (PMS) da palma forrageira cv. Gigante (Opuntia ficus-indica Mill) sob condições de irrigação, adensamento e adubação, com 12 meses de rebrota. O delineamento experimental foi inteiramente casualizado em esquema fatorial $(3 \times 2)$ com 12 repetições. Os tratamentos constaram de três intensidades de corte (preservando o cladódio mãe (PCM), os cladódios primários (PCP) e os secundários (PCS) e dois anos de colheita. Período experimental 24 meses e duas colheitas com intervalos de 12 meses. O solo foi classificado como Cambissolo Háplico e a água de irrigação C4S1 (CE 5,25 dS.m ${ }^{-1}$ ) e densidade de 50.000 plantas ha ${ }^{-1}$. Foram avaliados: altura e número de cladódios por planta (NCP), comprimento, largura, perímetro, espessura e área dos cladódios (AC), índice de área dos cladódios (IAC), PMV e PMS. Não foi observada interação significativa $(\mathrm{P}>0,05)$ dos tratamentos para as variáveis altura, NCP, IAC e PMV. Variáveis relacionadas à morfologia dos cladódios apresentaram interação significativa $(\mathrm{P}<0,05)$. $\mathrm{O}$ tratamento $\mathrm{PCS}$ resultou na maior $\mathrm{PMS}(\mathrm{P}<0,05)$ com produtividade média de 27,2 $\mathrm{Mg} \mathrm{ha}^{-1}$ ano $^{-1}$, quando comparada à PCP $\left(18,6 \mathrm{Mg} \mathrm{ha}^{-1}\right.$ ano $\left.^{-1}\right)$ ou PCM $\left(11,8 \mathrm{Mg} \mathrm{ha}^{-1}\right.$ ano $\left.^{-1}\right)$. O tratamento PCS no momento da colheita promoveu maior NCP e maior produtividade de forragem, sendo uma alternativa de manejo com vistas à sustentabilidade da palma cv. Gigante sob irrigação. As características morfológicas mais importantes também foram influenciadas pelas menores intensidades de corte.
\end{abstract}

Palavras-chave: Cactaceae. Irrigação. Opuntia fícus-indica. Reservas forrageiras. Semiárido.

\footnotetext{
*Corresponding author

${ }^{1}$ Received for publication in 08/28/2014; accepted in 02/16/2016.

${ }^{2}$ Department of Animal Production, Empresa de Pesquisa Agropecuária do Rio Grande do Norte, Parnamirim, RN, Brazil; guilhermeemparn@rn.gov.br, josegeraldomdsilva@gmail.com.

${ }_{3}^{3}$ Department of Animal Production, Coordenação de Aperfeiçoamento de Pessoal de Nível Superior/ Empresa de Pesquisa Agropecuária do Rio Grande do Norte, Parnamirim, RN, Brazil; margarethmaria_teles@yahoo.com.br.

${ }^{4}$ Department of Animal Production, Coordenação de Aperfeiçoamento de Pessoal de Nível Superior/Universidade Federal Rural de Pernambuco, Recife, PE, Brazil; fernandadgdz@hotmail.com.

${ }^{5}$ Embrapa Goats and Sheep, Empresa Brasileira de Pesquisa Agropecuária, Sobral, CE, Brazil; raimundo.lobo@embrapa.br.

${ }^{6}$ Academic Unit in Agricultural Sciences, Universidade Federal do Rio Grande do Norte, Macaíba - RN, Brazil; emersonaguiar@ufrnet.br.
} 


\section{INTRODUCTION}

The cattle industry in the Northeastern Brazilian semi-arid region is considered to pose less economic risk than agriculture. In this region, the rates of animal productivity are low, mainly due to the low carrying capacity of native pastures and the shortage of stored forage.

Sáenz (2013) has recognized the potential of the cactus pear (Opuntia and Nopalea) and its importance in contributing to the development of arid and semi-arid regions, with satisfactory results both for the environment and food security.

Lima et al. (2013) pointed out that the production of 1 ha of irrigated forage cactus $(25 \mathrm{Mg}$ DM ha ${ }^{-1} \mathrm{yr}^{-1}$ ) plus 2 ha of forage sorghum for silage (21 $\mathrm{Mg} \mathrm{DM} \mathrm{ha} \mathrm{yr}^{-1}$ ) allow family farmers to maintain the production of 20 cows or 200 goats or sheep over a period of 180 days of drought.

The cactus pear is a xerophilous plant with high efficiency of water use and it has met a considerable part of the forage demand for livestock in the conditions of the Brazilian semi-arid region. When well managed, Opuntia and Nopalea varieties can produce 50-60 times more forage per unit area than the native grasslands in semiarid environments (DUBEUX JR. et al, 2015); and with irrigation, show yields of $40-50 \mathrm{Mg} \mathrm{DM} \mathrm{ha}^{-1} \mathrm{yr}^{-1}$ (Nobel, 2001). This productivity has been confirmed in the Brazilian semiarid (30 $\mathrm{Mg} \mathrm{ha} \mathrm{yr}^{-1}$ ) using an irrigation drip system (LIMA et al., 2015).

In various Northeastern semiarid regions, however, forage cacti wilt and can die during the dry season due to excessive water loss, low relative humidity, high evapotranspiration and water deficit, and high temperatures, especially at night. The cactus pear is a CAM (crassulacean acid metabolism) plant and captures carbon dioxide $\left(\mathrm{CO}_{2}\right)$ at night to reduce water loss (TAIZ; ZEIGER, 2009).

Irrigation is a limited resource for a few areas of the semiarid Northeast, and the use of drip-type systems with a minimal use of water is an option for the cultivation of forage cacti in these regions. According to Snyman (2006), even a few millimeters of rain, which are almost of no value to common fodder plants, can be efficiently used by the fodder forage cactus.

According to Alves et al. (2007), management practices such as spacing, harvesting and fertilization are closely related to the productivity of the forage cactus. The work of these authors showed that the preservation of the secondary cladodes of cactus pear cv. Gigante led to an increase in productivity.

The high yield potential of cactus pear fresh matter is confirmed in the literature with a production of $227.0 \mathrm{Mg} \mathrm{ha}^{-1}$ reported using drip irrigation and 75 days of growth in Mexico, with a planting density of 125,000 plants $\mathrm{ha}^{-1}$ (PINOSRODRIGUEZ et al., 2010) and $450 \mathrm{Mg} \mathrm{ha}^{-1}$ for hydroponic cultivation for six months
(RAMÍREZ-TOBIAS et al., 2010). Yields up to 22.7 and $20.2 \mathrm{Mg} \mathrm{DM} \mathrm{ha}^{-1}$ two years ${ }^{-1}$ are reported by Dubeux Junior and Santos (2005) in Pernambuco State, Brazil, with a density of 40,000 plants ha ${ }^{-1}$, for the cultivars Gigante and Miúda, respectively.

The objective of the research was to evaluate the effect of different cutting intensities and years of harvesting on the morphological characteristics and productivity of irrigated cactus pear cv. Gigante at a high planting density, with 12 months of regrowth.

\section{MATERIAL AND METHODS}

The experiment was conducted at the Terras Secas Experimental Station, in the municipality of Pedro Avelino, RN, Brazil, which belongs to the Agricultural Research Corporation of Rio Grande do Norte, EMPARN. The municipality is located between the geographic coordinates: latitude $5^{\circ}$ $31^{\prime} 21^{\prime \prime} \mathrm{S}$, longitude $36^{\circ} 23^{\prime} 14^{\prime \prime} \mathrm{W}$ and at an altitude of $68 \mathrm{~m}$. The climate according to the Koppen classification is the type BSs'h semiarid and according to Gaussen, is type 4aTh, warm tropical and markedly dry. According to INMET (2005), the mean annual rainfall of the region is $473 \mathrm{~mm}$. During the research period until the first harvest (June 2011 to June 2012), a rainfall of $409.3 \mathrm{~mm}$ was recorded, whereas in the second year (June 2012 to June 2013), the rainfall was $168.6 \mathrm{~mm}$. According to IDEMA (2008), the mean annual temperature in the research region area reached a maximum of $32^{\circ} \mathrm{C}$ and a minimum of $21^{\circ} \mathrm{C}$; the mean relative humidity was $70 \%$ and $2,400 \mathrm{~h}$ of sunshine were received per year.

The soil of the experimental area was classified as Cambisol Haplicum Eutrophic, with a Caatinga hyperxerophilic phase and a plan relief. The soil is well-drained, with a sandy $\left(648 \mathrm{~g} \mathrm{~kg}^{-1}\right)$ and clay $\left(220 \mathrm{~g} \mathrm{~kg}^{-1}\right)$ texture, and a moderately alkaline or neutral reaction. The chemical analysis of the Laboratory of Soil, Water and Plants of EMPARN indicated high values of calcium and potassium and low phosphorus availability, with the following composition: $\mathrm{Ca}=4.60$ cmolc. $\mathrm{dm}^{-3}, \mathrm{Mg}=$ 2.35 cmolc. $\mathrm{dm}^{-3}, \mathrm{P}=4.00 \mathrm{mg} \cdot \mathrm{dm}^{-3}, \mathrm{~K}=136,00$ mg.dm ${ }^{-3}, \mathrm{Na}=66.00 \mathrm{mg} \cdot \mathrm{dm}^{-3}$ and $\mathrm{pH}$ of 7.09 .

The cactus pear cv. Gigante (Opuntia ficusindica Mill.) was planted in January 2010. The cladodes were left in the shade for seven days, and were subsequently planted with a spacing of $2.0 \times$ $0.10 \mathrm{~m}\left(50,000\right.$ plants $\left.\mathrm{ha}^{-1}\right)$, by placing the cladodes vertically into the soil to a sufficient depth $(20 \mathrm{~cm})$, so that half of each cladode was buried in the ground.

The trial period lasted 24 months and consisted of two harvests separated by a 12 -month interval after the first uniform cut 17 months after planting.

On 20 June 2011, the standardization cut was performed, with the establishment of cutting 
treatments using the organic fertilizer of $40 \mathrm{Mg} \mathrm{ha}^{-1}$ natural cattle manure, $50 \mathrm{~kg}$ urea $\mathrm{ha}^{-1}$ and $500 \mathrm{~kg}$ single superphosphate $\mathrm{ha}^{-1}$ in a single application. The cattle manure used had the following composition according to the analysis performed by the Laboratory of EMPARN: moisture $=10 \%$; organic $\mathrm{C}=27 \% ; \mathrm{N}=18.89 \mathrm{~g} \mathrm{~kg}^{-1} ; \mathrm{P}=6.70 \mathrm{~g} \mathrm{~kg}^{-1}$; $\mathrm{K}=32.53 \mathrm{~g} \mathrm{~kg}^{-1} ; \mathrm{Ca}=15.88 \mathrm{~g} \mathrm{~kg}^{-1} ; \mathrm{Mg}=9.79 \mathrm{~g} \mathrm{~kg}^{-}$ ${ }^{1} ; \mathrm{Na}=5.66 \mathrm{~g} \mathrm{~kg}^{-1} ; \mathrm{Zn}=142.00 \mathrm{mg} \mathrm{kg}{ }^{-1} ; \mathrm{Cu}=64.00$ $\mathrm{mg} \mathrm{kg} ; \mathrm{Fe}=4,550.00 \mathrm{mg} \mathrm{kg}^{-1} ; \mathrm{Mn}=200.00 \mathrm{mg} \mathrm{kg}^{-}$

A completely randomized factorial design (3 $\times 2)$ was applied, with 12 replicates. The treatments consisted of three cutting intensities: preserving only the mother cladode (PMC), preservation of all primary cladodes (PPC) or preservation of all secondary cladodes (PSC) and two harvest years.

The results were derived from two harvests performed on 22 June 2012 and 24 June 2013 at intervals of 12 months of regrowth. After the first cut was made, a new fertilization with $40 \mathrm{Mg} \mathrm{ha}^{-1}$ cattle manure (natural material), $500 \mathrm{~kg} \mathrm{ha} \mathrm{ha}^{-1}$ superphosphate; $150 \mathrm{~kg} \mathrm{ha}^{-1}$ urea and $50 \mathrm{~kg} \mathrm{ha}^{-1}$ potassium chloride, according to the recommendation of the Laboratory of Soil, Water and Plants of EMPARN. The chemical fertilizer was applied once, whereas organic fertilization was performed by two applications; the first 13 August 2012 and the second on 15 March 2013. The organic fertilizer used in the second year had the following quantitative composition, according to the EMPARN Laboratory: moisture $=37 \%$; organic $\mathrm{C}=15 \% ; \mathrm{N}=$ $15.41 \mathrm{~g} \mathrm{~kg}^{-1} ; \mathrm{P}=5.91 \mathrm{~g} \mathrm{~kg}^{-1} ; \mathrm{K}=26.74 \mathrm{~g} \mathrm{~kg}^{-1} ; \mathrm{Ca}=$ $12.39 \mathrm{~g} \mathrm{~kg}^{-1} ; \mathrm{Mg}=11.55 \mathrm{~g} \mathrm{~kg}^{-1} ; \mathrm{Na}=5.03 \mathrm{~g} \mathrm{~kg}^{-1} ; \mathrm{Zn}$ $=134.00 \mathrm{mg} \mathrm{kg}{ }^{-1} ; \mathrm{Cu}=64.00 \mathrm{mg} \mathrm{kg}{ }^{-1} ; \mathrm{Fe}=$ $13,650.00 \mathrm{mg} \mathrm{kg}^{-1} ; \mathrm{Mn}=425.00 \mathrm{mg} \mathrm{kg}^{-1}$.

The irrigation water during the two-year experiment was applied as $5 \mathrm{~L}$ per linear $\mathrm{m}(2.5 \mathrm{~mm})$ every seven days, totaling $10 \mathrm{~mm}$ per month, with the independent application of the rainfall index. The irrigation system used was dripping in single rows and the irrigation water was classified according to Pizarro (1985), as C4S1, with a high salinity and high levels of chlorides, as shown by the results of chemical analysis, performed by the EMPARN Laboratory, which showed the following results: $\mathrm{pH}$ =7.2; $\mathrm{EC}=5.25 \mathrm{dS} \mathrm{m}^{-1} ; \mathrm{Ca}=19.45 \mathrm{mmol} \mathrm{L}^{-1} ; \mathrm{Mg}=$ $16.65 \mathrm{mmol} \mathrm{L}^{-1} ; \mathrm{Na}=16.05 \mathrm{mmol} \mathrm{L}^{-1} ; \mathrm{K}=0.30$ $\mathrm{mmol} \mathrm{L}{ }^{-1} ; \mathrm{Cl}=51.39 \mathrm{mmol} \mathrm{L}^{-1} ; \mathrm{CO}^{3-}=0.00 \mathrm{mmol} \mathrm{L}$ ${ }^{-1} ; \mathrm{HCO}_{3^{-}}=4.76 \mathrm{mmol} \mathrm{L}^{-1}$ and $\mathrm{RAS}^{\circ}=4.77$.

The measurable area of the plot was $2 \mathrm{~m}^{2}$, corresponding to 10 plants in the central $\mathrm{m}$ of the plots with dimensions of $6 \mathrm{~m}^{2}$, with $1 \mathrm{~m}$ on each side as borders. At the end of each period, the following variables were evaluated: plant height, the number of cladodes per plant (NC), the length, width, perimeter and thickness of the cladodes, the area of the cladodes (AC), the cladode area index (CAI), fresh- matter production (FMP) and dry-matter production (DMP) of cactus pear cv. Gigante with 12 months of regrowth. The FMP was calculated by cutting and weighing 10 plants within the central meter of the sample area $\left(2 \mathrm{~m}^{2}\right)$, which were harvested according to the cutting intensity treatment. To determine the $\mathrm{DM}$, a cladode sample of about $1 \mathrm{~kg}$ was collected and weighed, and was then dried in a forced circulation oven at $55^{\circ} \mathrm{C}$ according to Silva and Queiroz (2009) before reweighing and calculation of the DM yield.

The height of the plants and the length, width and perimeter of the cladodes were measured using a tape-measure and the thickness of the cladodes was measured with a digital caliper. The AC and CAI were calculated according to Santos (1992) using the equations for cactus pear cv. Gigante: $\mathrm{AC}=$ $211.5104+8,8649 \mathrm{P}(\mathrm{P}=$ perimeter $)$ and $\mathrm{CAI}=$ the $\mathrm{AC}$ of a plant/soil area of a plant.

Data were subjected to analysis of variance by analysing the effects of cutting intensities, year of harvesting and their interaction, using the statistical analysis SAS program version 8 as a tool. When significant differences between treatments for the different variables were detected, they were compared using the Bonferroni test at 5\% probability.

\section{RESULTS AND DISCUSSION}

There was no significant interaction $(P>$ $0.05)$ among treatments for the variables plant height, NC and CAI. A significant effect was observed $(P<0.05)$ for height, NC and CAI (Table $1)$, depending on the cutting intensity, and for $\mathrm{NC}$ and CAI, depending on the year of harvesting.

There was a higher mean plant height (143.73 $\mathrm{cm})$ for the PSC treatment, an intermediate value $(114.01 \mathrm{~cm})$ for the PPC treatment and a lower height $(81.11 \mathrm{~cm})$ in the PMC treatment. Ferreira et al. (2003) reported maximum and minimum heights of $70.2 \mathrm{~cm}$ and $122.9 \mathrm{~cm}$, respectively, for Opuntia ficus indica Mill. harvested at two years of age. Assessing the morphogenesis of varieties of dripirrigated fodder forage cactus, cv. Miúda, IPASertânia and Orelha de Elefante Mexicana, Pereira et al. (2015) reported a mean height of $48.8 \mathrm{~cm}$ after 12 months of growth.

The highest mean height recorded at the lowest cutting intensity can be explained by this treatment having largest remaining photosynthetic area. There was no difference in plant height $(P>$ $0.05)$ between the two harvest years, demonstrating a high recovery ability of the plants within an interval of 12 months, even at the heaviest cutting intensity that only left the mother cladode. 
Table 1. Plant height $(\mathrm{cm})$, number of cladodes/plant and cladode area index (CAI), of cactus pear cv. Gigante with 12 months regrowth, according to the cutting intensity and the year of harvesting.

\begin{tabular}{cccr}
\hline Year & $\begin{array}{c}\text { Height } \\
(\mathrm{cm})\end{array}$ & $\begin{array}{c}\text { No. Cladodes/ } \\
\text { plant }\end{array}$ & CAI \\
\hline Year 01 & $115.27 \mathrm{a}$ & $12.29 \mathrm{~b}$ & $3.38 \mathrm{~b}$ \\
Year 02 & $109.97 \mathrm{a}$ & $16.68 \mathrm{a}$ & $5.01 \mathrm{a}$ \\
& & & \\
CI - Cutting intensity & $81.11 \mathrm{c}$ & $8.60 \mathrm{c}$ & $2.12 \mathrm{c}$ \\
PMC & $114,01 \mathrm{~b}$ & $14,26 \mathrm{~b}$ & $4,08 \mathrm{~b}$ \\
PPC & $143.73 \mathrm{a}$ & $20.60 \mathrm{a}$ & $6.38 \mathrm{a}$ \\
PSC & 2.83 & 10.11 & 24.35 \\
\hline CV \% & & &
\end{tabular}

Means followed by the same letter in the column segments (Years / CI) do not differ by the Bonferroni Test $(\mathrm{P}>0,05)$.

The analysis of variance revealed significant differences in NC (Table 1), with the highest mean value (20.6) observed in the PSC treatment. The cutting management with PPC resulted in more cladodes per plant (14.26) than in the PMC treatment (8.60). These results indicate that the cutting intensity management is fundamentally important to obtain higher yields and that the vegetative growth of this cactus can be influenced by a greater number of regrowth points and a large amount of remaining photosynthetic area, if all secondary cladodes are preserved. Nobel (2001) reported that the existence of more cladodes per unit area tends to increase the $\mathrm{CO}_{2}$ capture and to maximize productivity.

Nascimento et al. (2011), working with cactus pear cv. Gigante with a dense planting spacing of 1.7 $\times 0.10 \mathrm{~m}\left(58,800\right.$ plants $\left.\mathrm{ha}^{-1}\right)$ and an organic fertilization rate of $30 \mathrm{Mg} \mathrm{ha}^{-1}$, found 11.9 cladodes per plant after 11 months of growth.

In general, the $\mathrm{NC}$ at the cutting intensities of PSC and PPC was higher than that reported in the literature. Ramos et al. (2011) found 11.45 cladodes per plant for 15-month-old cactus pear Opuntia ficus -indica. Almeida et al. (2012) reported that a spacing of $1.0 \mathrm{~m} \times 0.25 \mathrm{~m}$ and organic fertilization with cattle manure $\left(30 \mathrm{Mg} \mathrm{ha}^{-1}\right)$ resulted in a mean of 16 cladodes per plant following harvest at 24 months of age. Silva et al. (2010) evaluated the morphological characteristics of 49 clones of Opuntia and found a mean of 12.5 cladodes per plant. These numbers highlight the importance of leaving a high residual photosynthetically active area after harvest, especially secondary cladodes, to accelerate the recovery of cactus plantations.

A large area of cladodes (AC) remaining following cutting by maintaining the secondary cladodes might also favor the further growth of plants, since the cladodes photosynthesize and hence, affect biomass production.
The PSC treatment resulted in a higher CAI value than the PPC or PMC treatment (Table 1). This suggests that the cactus pear has a low carbohydrate reserve, because the plants recover more rapidly $\mathrm{f}$ ollowing a more severe cut (as in PMC) and the residual cladode area is important for this species, which depends on a minimum area of cladodes to sprout vigorously.

The increase in the number of shoots following the PSC cutting intensity promoted a greater CAI and thereby, maximized forage production. Several factors might contribute to an increase in cactus pear forage production, such as a large cladode area and the spacing used. Dubeux Jr. et al. (2006) evaluated different planting densities for forage cactus and found that plantations with populations of 40,000 plants $\mathrm{ha}^{-1}$ resulted in a higher CAI and dry matter production than densities of 5,000 plants $\mathrm{ha}^{-1}$.

The CAI was higher for the PSC treatment (6.38); was intermediate in the PPC treatment (4.08) and lower for the PMC treatment (2.12). A low CAI of 2.2 was obtained by Sales et al. (2013) for cactus pear cv. Gigante at a high density $(50,000$ plants $\left.\mathrm{ha}^{-1}\right)$, when the harvest preserved all primary cladodes at 23 months of growth. These differences might relate to irrigation, which resulted in more palm shoots and consequently, a greater CAI.

Variables related to cladode morphology, such as length, width, thickness and area, showed significant interactions $(P<0.05)$ with the cutting intensity and year of harvesting (Table 2 ).

The mean length of cladodes did not differ between the two years of harvesting for the cutting intensities PSC and PPC. According to Mondragón and Pérez-González (2001), cladode length is hardly influenced by management and is more dependent on the genotype, which might explain the lack of difference observed here. 
Table 2. Length, width, thickness and area of cactus pear cv. Gigante cladodes with 12 months of regrowth, according to the cutting intensity and year of harvesting.

\begin{tabular}{|c|c|c|c|c|c|}
\hline \multirow{2}{*}{ Variable } & & \multicolumn{3}{|c|}{ Intensity of cutting } & \multirow{2}{*}{$\mathrm{CV} \%$} \\
\hline & & PMC & $\mathrm{PPC}$ & $\mathrm{PSC}$ & \\
\hline \multirow{2}{*}{$\begin{array}{l}\text { Length } \\
\text { (cm) }\end{array}$} & Year 01 & $33.03 \mathrm{~b} \mathrm{~A}$ & $36.72 \mathrm{ab} \mathrm{A}$ & 39.91 a A & \multirow{2}{*}{22.36} \\
\hline & Year 02 & $34.14 \mathrm{~b} \mathrm{~A}$ & 39.61 a A & 39.86 a A & \\
\hline \multirow{2}{*}{$\begin{array}{l}\text { Width } \\
(\mathrm{cm})\end{array}$} & Year 01 & $16.33 \mathrm{c} \mathrm{A}$ & $18.97 \mathrm{~b} \mathrm{~B}$ & $21.26 \mathrm{a} \mathrm{A}$ & \multirow{2}{*}{10.44} \\
\hline & Year 02 & $18.25 \mathrm{~b} \mathrm{~A}$ & $21.61 \mathrm{a} \mathrm{A}$ & $23.00 \mathrm{a} \mathrm{A}$ & \\
\hline \multirow{2}{*}{$\begin{array}{l}\text { Thickness } \\
(\mathrm{mm})\end{array}$} & Year 01 & $14.53 \mathrm{a} \mathrm{A}$ & 15.97 a B & 16.94 a A & \multirow{2}{*}{20.36} \\
\hline & Year 02 & $16.28 \mathrm{~b} \mathrm{~A}$ & $19.50 \mathrm{ab} \mathrm{A}$ & 20.08 a A & \\
\hline \multirow{2}{*}{$\begin{array}{l}\text { Cladode area } \\
\qquad\left(\mathrm{cm}^{2}\right)\end{array}$} & Year 01 & $460.01 \mathrm{c} \mathrm{A}$ & $529.20 \mathrm{~b} \mathrm{~B}$ & 592.85 a A & \multirow{2}{*}{12.39} \\
\hline & Year 02 & $508.52 \mathrm{~b} \mathrm{~A}$ & 605.54 a A & 636.32 a A & \\
\hline
\end{tabular}

Means followed by same lowercase letters in the line or means followed by the same capital letters in columns for each variable do not differ according to the Bonferroni test $(P>0.05)$.

Some of the differences observed for the width and thickness of the cladodes might be the result of a higher efficiency of physiological and biochemical processes, such as photosynthesis, respiration and transpiration, which are influenced by harvesting management practices that leave a higher residual area. Ferreira et al. (2003) obtained a cladode length of $33.6 \mathrm{~cm}$ and width of $18.27 \mathrm{~cm}$ for cactus pear at a spacing of $1.0 \mathrm{~m} \times 0.5 \mathrm{~m}$ and that received organic fertilizer associated with chemical fertilizer after 24 months of growth. It appears that the maintenance of a higher CAI maintains a level of light interception that is close to the maximum, leading to high rates of $\mathrm{CO}_{2}$ fixation and thus, to a higher growth of cladodes.

Teles et al. (2002) evaluated the effect of fertilization and nematicides on the growth and production of cactus pear cv. Gigante and did not observe a significant effect between treatments on the thickness of the cladodes. The authors found a mean length and width of cladodes of $29.11 \mathrm{~cm}$ and $11.79 \mathrm{~cm}$, respectively. These values are lower than those in this study, which might relate to the age of the plant, because they studied cactus pear cv. Gigante that was nine months of age.

The PSC cutting intensity caused the greatest $\mathrm{AC}$ after the first harvest and differences between PPC and PMC in the second harvest. Photosynthesis is a key factor of productivity and growth of forage plants, thus, the remaining cladode area after cutting the forage is directly related to growth. Donato et al. (2014) recorded a mean cladode area of $350 \mathrm{~cm}^{2}$ for 20-month-old cactus pear cv. Gigante under different spacing and organic fertilizer levels, which is a lower value than that in this study, which might be related to the use of irrigation and chemical fertilizers. Oliveira Jr. et al. (2009) evaluated the vegetative growth of the cactus pear Opuntia ficus-indica Mill, in response to spacing, and obtained cladodes with an area of $376.2 \mathrm{~cm}^{2}$ in 11 -month-old plants. For these authors, the vegetative growth of cactus pear cladodes can be measured by the area, which is a useful variable with which to estimate the photosynthetic capacity of the plant and is a useful variable to measure vegetative growth.

There was no significant interaction $(P>$ 0.05 ) among the treatments for the variable fresh matter production (FMP), which was affected by the cutting intensity and year of harvesting. The highest FMP was obtained in the PSC treatment with 249.71 $\mathrm{Mg} \mathrm{ha}^{-1} \mathrm{yr}^{-1}, 128.19 \mathrm{Mg} \mathrm{ha}^{-1} \mathrm{yr}^{-1}$ for PPC and 75.11 $\mathrm{Mg} \mathrm{ha}^{-1} \mathrm{yr}^{-1}$ for PMC. Similar values to those for the same cutting intensities were obtained by Lima et al. (2015) with the irrigated forage cactus cv. Miúda (Nopalea cochenillifera), with a FMP productivity of 227.67, 173.11 and $95.09 \mathrm{Mg} \mathrm{ha}^{1} \mathrm{yr}^{-1}$, respectively.

Significant interaction was found $(P<0.05)$ between the treatments for dry matter production (DMP), because the responses in the PSC and PPC treatments varied between years (Table 3 ).

In general, there was an increase in the mean DMP between the first and second harvests, despite a severe drop in the amount of precipitation from $409.3 \mathrm{~mm}$ to $168.6 \mathrm{~mm}$ and maintaining irrigation at $120 \mathrm{~mm} \mathrm{year}^{-1}$. These yield increases can be attributed to the increase in the number of cladodes per plant and in the CAI, which is promoted by the lower cutting intensities, the aging of the cactus pear plantation, and especially, the cumulative effect of organic and chemical fertilizers.

Evaluating the forage cactus productivity of irrigated cultivar Orelha de Elefante Mexicana (Opuntia stricta) with a planting density of 15,625 plants/ha $(1.6 \times 0.4 \mathrm{~m})$ and 12 months of growth, Queiroz et al. (2015) obtained $8.18 \mathrm{Mg} \mathrm{ha}^{-1}$ of DM (131.16 $\mathrm{Mg} \mathrm{FM} \mathrm{ha}^{-1}$ ), by preserving only the basal (mother) cladodes. These results are similar to those obtained with the same type of cut in the first harvest here, but are well below the yield obtained with the PSC and PPC treatments. In this case, in addition to 
Table 3. Dry matter production $\left(\mathrm{Mg} \mathrm{ha}^{-1} \mathrm{yr}^{-1}\right)$ of cactus pear cv. Gigante with 12 months of regrowth, according to the cutting intensity and year of harvesting.

\begin{tabular}{ccccc}
\hline \multirow{2}{*}{ Year } & & \multicolumn{2}{c}{ Intensity of cutting } & CV (\%) \\
\hline 01 & PMC & PPC & PSC & CV \\
02 & $14.62 \mathrm{c} \mathrm{B}$ & $14.83 \mathrm{~b} \mathrm{~B}$ & $19.64 \mathrm{a} \mathrm{B}$ & 15.31 \\
\hline
\end{tabular}

Means followed by the same lowercase letters in the line or the same capital letters in columns do not differ according to the Bonferroni test $(P>0.05)$.

the cutting intensity, the high-density of 50,000 plants $\mathrm{ha}^{-1}$ in the trial probably contributed to the high yields.

In a trial with forage cactus cv. Miúda (Nopalea cochenillifera) irrigated with $30 \mathrm{~mm}$ month ${ }^{-1}$, preserving the secondary cladodes and with a density of 20,000 plants ha ${ }^{-1}$, Dantas (2015) obtained a DMP of $13.5 \mathrm{Mg} \mathrm{ha}^{-1}$ year $^{-1}$, which is lower than other reported values with 50,000 plants ha ${ }^{-1}$.

These results corroborate those of Alves et al. (2007), who studied different frequencies and intensities of cutting of cactus pear cv. Gigante and found higher forage yields following preservation of the secondary cladodes. According to the authors, this was due to the increase in the residual CAI after the harvest, enabling the plants to maintain a higher photosynthetic efficiency.

The high forage yield with PSC management can also be explained by the greater number of regrowth bud points remaining after cutting, as well as the larger residual photosynthetic area. Other factors that might also have led to the high yields observed in this study are the use of irrigation, high planting densities, as well as the use of chemical and organic fertilizers.

Silva et al. (2010) evaluated the morphological and productive characteristics of 50 clones of forage cactus and obtained a mean DM yield of $7.1 \mathrm{Mg} \mathrm{ha}^{-1}$ after two years of growth, using a cutting intensity that left only the mother cladode. This value is lower than that in this study, which might be associated with the higher amounts of manure and irrigation used in the experiments here, in addition to the negative effects caused by cutting that preserved only the mother cladode.

The efficiency of plants to convert light energy via photosynthesis depends among other factors, on the area of the cladodes remaining after cutting. Therefore, the production of FM and DM were probably favored by the increased budding of new cladodes, resulting from the PSC management and favorable growth conditions due to irrigation, planting density and chemical and organic fertilizers.

The mean annual yield of DM in both harvests can be considered extremely high, with maximum yields of $34.7 \mathrm{Mg} \mathrm{DM} \mathrm{ha} \mathrm{yr}^{-1}$ following the maintenance of all secondary cladodes.

The increase in forage productivity observed after two cuts with a 12-month interval, using irrigation water with a high salinity of only $10 \mathrm{~mm}$ month $^{-1}$ is also notable. Cunha et al. (2012) suggests that the death of the roots of forage cactus at the start of the dry season is a mechanism to save nutrients and water by plants. Therefore, irrigation that ensures the survival and full growth of the roots might explain the high yields achieved.

In grasses, the speed of regrowth depends on the amount of leaf area remaining after cutting, the availability of growth points (apical meristems) and the organic reserves of the plant. The results indicate that for the forage cactus, similar to the cactus pear cv. Gigante, preserving a large area of cladodes after the harvest (PSC or PPC) increases the rate of regrowth, which results in an increased photosynthetic efficiency and thus, an increased formation of new cladodes and an increased forage production. Pessoa (1967) considers that secondary cladodes are important for the formation of the plants, since they provide the future structure of the plant, which should be preserved in future cuts and directly reflects the precocity and production of plants.

\section{CONCLUSION}

The preservation of the secondary cladodes at harvest promoted more cladodes per plant and a higher productivity of forage and therefore, represents a management alternative to promote a greater sustainability of cactus pear cv. Gigante under irrigation. The most important morphological characteristics were also influenced by lower cutting intensities.

\section{ACKNOWLEDGMENT}

We acknowledge the Banco do Nordeste do Brasil/ETENE-FUNDECI for the financial support for the research.

\section{REFERENCES}

ALMEIDA, J.; PEIXOTO, C. P.; LEDO, C. A. S. Desempenho vegetativo da palma forrageira. Enciclopédia Biosfera, Centro Científico Conhecer, Goiânia, v. 8, n. 15, p. 571-581, 2012. 
ALVES, R. N. et al. Produção de forragem pela palma após 19 anos sob diferentes intensidades de corte e espaçamentos. Revista Caatinga, Mossoró, v. 20, n. 4, p. 38-44, 2007.

CUNHA, D. N. F. V. et al. Morfometria e acúmulo de biomassa em palma forrageira sob doses de nitrogênio. Revista Brasileira de Saúde e Produção Animal, Salvador, v. 13, n. 4, p. 11561165, 2012.

DANTAS, F. D. G. Lâminas de água salina e doses de adubação orgânica na produção de palma Miúda adensada no semiárido. 2015. 92 f. Dissertação (Mestrado em Produção Animal: Área de Concentração em Produção Animal) Universidade Federal do Rio Grande do Norte, Macaíba, 2015.)

DONATO, P. E. R. et al. Morfometria e rendimento da palma forrageira 'Gigante' sob diferentes espaçamentos e doses de adubação orgânica. Revista Brasileira de Ciências Agrárias, Recife, v. 9, n. 1, p. 151-158, 2014.

DUBEUX JÚNIOR, J. C. B.; SANTOS, M. V. F. Exigências nutricionais da palma forrageira. In: MENEZES, R. S. C.; SIMÕES, D. A.; SAMPAIO, E. V. S. B. (Eds.). A palma no Nordeste do Brasil, conhecimento atual e novas perspectivas de uso. Recife-PE: Ed. Universitária/UFPE, 2005. p. 105128.

DUBEUX JÚNIOR, J. C. B. et al. Productivity of Opuntia-ficus (L.) Miller under different $\mathrm{N}$ and $\mathrm{P}$ fertilization and plant population in north-east Brazil. Journal of Arid Environments, Amsterdam, v. 67, n. 3 , p. $357-372,2006$.

DUBEUX JR., J. C. B. et al. Forage potential of cacti on drylands. Acta Horticulturae (ISHS), Leuven, v. 1. n. 1067-24, p. 181-186, 2015.

FERREIRA, C. A. et. al. Utilização de técnicas multivariadas na avaliação da divergência genética entre clones de palma forrageira (Opuntia ficusindica Mill). Revista Brasileira de Zootecnia, Viçosa, v. 32, n. 6, p. 1560-1568, 2003.

\section{INSTITUTO DE DESENVOLVIMENTO} SUSTENTÁVEL E MEIO AMBIENTE - IDEMA. Perfil do seu município - Pedro Avelino. Natal, SEMARH. 2008. 33 p.

INSTITUTO NACIONAL DE METEOROLOGIA INMET. Normais climatológicas do Brasil 19611990. RAMOS, A. M.; SANTOS, L. A. R.; FORTES, L. T. G. (Eds.). Brasília. INMET, 2005. $465 \mathrm{p}$.
LIMA, G. F. C. et. al. Situación actual de las técnicas de producción de nopal forrajero en Brasil: avances y limitaciones. In: MONDRAGÓN-JACOBO, C. (Ed.). Simposio Internacional Tuna Nopal 2013. Puebla-México: SAGARPA, 2013. p. 94-105.

LIMA, G. F. C et al. Effect of different cutting intensities on morphological characteristics and productivity of irrigated Nopalea forage cactus. Acta Horticulturae (ISHS), Leuven, v. 1, n. 1067-35, p. $253-258,2015$

MONDRAGÓN-JACOBO, C.; PÉREZGONZÁLEZ, S. Germoplasm resources and breeding Opuntia for fodder production. In: MONDRAGÓN-JACOBO, C.; PÉREZGONZÁLEZ, S. (Eds.). Cactus (Opuntia spp.) as forage. Rome: FAO, 2001. p. 21-28.

NASCIMENTO, J. P. et. al. Caracterização morfométrica de Opuntia ficus-indica sob diferentes arranjos populacionais e fertilização fosfatada. Tecnologia \& Ciência Agropecuária, João Pessoa, v. 5 , n. 3 , p. $21-26,2011$.

NOBEL, P. S. Biologia Ambiental. In: BARBERA, G.; INGLESA, P.; PIMIENTA-BARRIOS, E. (Eds.) Agroecologia, cultivo e usos da palma forrageira. Roma: FAO/Sebrae-PB, 2001. p. 36-48.

OLIVEIRA JÚNIOR, S. et. al. Crescimento vegetativo da palma forrageira (Opuntia ficus indica) em função do espaçamento no semiárido paraibano. Tecnologia \& Ciência Agropecuária, João Pessoa, v. 3, n. 1, p. 7-12, 2009

PEREIRA, P. C. et al. Morfogênese da palma forrageira irrigada por gotejamento. Revista Caatinga, Mossoró, v. 28, n. 3, p. 189-195, 2015.

PESSOA, A. S. Cultura da palma forrageira. Recife: SUDENE/Divisão de Documentação, 1967. 99 p. (Coleção Agricultura, 5).

PINOS-RODRIGUEZ, J. M. et. al. Effects of cladode age on biomass yield and nutritional value of intensively produced spineless cactus for ruminants. South African Journal of Animal Science, Hatfield, v. 40, n. 3, p. 245-250, 2010.

PIZARRO, F. Drenaje agrícola y recuperacion de suelos salinos. 2. ed. Madrid: Editorial Española S. A, $1985.542 \mathrm{p}$

QUEIROZ, M.G. et al. Características morfológicas e produtividade da palma forrageira em diferentes lâminas de irrigação. Revista Brasileira de Engenharia Agrícola a Ambiental, Campina Grande, v. 19, n. 10, p. 931-938, 2015. 
RAMÍREZ-TOBIAS, H. M. et al. Nopalito and forage productivity of Opuntia spp. and Nopalea sp. (Cactaceae) growing under greenhouse hydroponics system. Journal of Food, Agriculture \& Environment, Helsink, v. 8, n. 3-4, p. 660-665, 2010.

RAMOS, J. P. F. et. al. Crescimento vegetativo de Opuntia fícus-indica em diferentes espaçamento. Revista Caatinga, Mossoró, v. 24, n. 3, p. 41-48, 2011.

SÁENZ, C. Opuntias as a natural resource. In: SÁENZ, C. et al. (Ed.) Agro-industrial utilization of cactus pear. Rome: FAO, 2013. p. 17-21.

SALES, A. T. et. al. Crescimento vegetativo da palma forrageira em diferentes densidades de plantio no Curimatu Paraibano. Tecnologia \& Ciência Agropecuária, João Pessoa, v. 7, n. 1, p. 19-24, 2013.

SANTOS, D. C. Estimativa de parâmetros em caracteres de clones da palma forrageira (Opuntia ficus indica Mill e Nopalea cochenillifera SalmDick).1992. 119 f. Dissertação (Mestrado em Zootecnia: Área de Concentração em Produção Animal) - Universidade Federal Rural de Pernambuco, Recife, 1992.

SILVA, D. J.; QUEIROZ, A. C. Análises de alimentos (métodos químicos e biológicos). 3. ed. Viçosa: UFV, 2009. 235 p.

SILVA, N. G. M. et. al. Relação entre características morfológicas e produtivas de clones da palma forrageira. Revista Brasileira de Zootecnia, Viçosa, v. 39, n. 11, p. 2389-2397, 2010.

SNYMAN, H. A. Root distribution with changes in distance and depth of two-year-old cactus pears Opuntia ficus-indica and O. robusta plants. South Africa Journal of Botany, Pietermaritzburg, v. 72, n. 3, p. 434-441, 2006.

TAIZ, L.; ZEIGER, E. Fisiologia vegetal. 4 ed. Porto Alegre: Artmed Editora S. A, 2009. p 188-190.

TELES, M. M. et. al. Efeitos da adubação e de nematicida no crescimento e na produção da palma forrageira (Opuntia ficus indica Mill) cv. gigante. Revista Brasileira de Zootecnia, Viçosa, v. 31, n. 1, p. 52-60, 2002. 